\title{
Giant cell myocarditis, in a patient with Crohn's disease, treated with etanercept - a tumour necrosis factor-alpha antagonist
}

\author{
CL Nash MD FRCPC, R Panaccione MD FRCPC, LR Sutherland MD FRCPC, JB Meddings MD FRCPC
}

CL Nash, R Panaccione, LR Sutherland, JB Meddings. Giant cell myocarditis, in a patient with Crohn's disease, treated with etanercept - a tumour necrosis factor-alpha antagonist. Can J Gastroenterol 2001;15(9):607-611. Cardiac disease in association with inflammatory bowel disease (IBD) is uncommon. Reports include pericarditis, pericardial effusion, myocarditis, myocardial infarction, endocarditis and arrythmias. Myocardial inflammation related to IBD may be due to a drug hypersensitivity reaction or micronutrient deficiency, or may be secondary to the underlying IBD as an extraintestinal manifestation. In this setting, myocarditis usually presents as congestive heart failure and/or refractory arrhythmia. Prognosis varies among reported cases, including complete recovery, remission with recurrence and fatal disease. Treatment of myocarditis has included aminosalicylates and immunosuppressive medications. Recently, newer therapies for IBD have been developed, such as tumour necrosis factor-alpha (TNF- $\alpha$ ) antagonists. The present report describes a case of a 46-year-old man with clinical and endoscopic evidence of moderately active colonic Crohn's disease who developed congestive heart failure due to giant cell myocarditis. Little clinical improvement occurred with immunosuppressive therapy.
Only after the addition of etanercept, a TNF- $\alpha$ p 75 receptor antagonist, did complete clinical resolution occur. These authors conclude that the use of TNF- $\alpha$ antagonists may be considered in the treatment of life-threatening extraintestinal manifestations of inflammatory bowel disease.

Key Words: Crohn's disease; Etanercept; Giant cell myocarditis; Inflammatory bowel disease; Tumour necrosis factor-alpha antagonist

Myocardite à cellules géantes chez un patient atteint de la maladie de Crohn et traité à l'étanercept, un antagoniste du facteur de nécrose tumorale alpha

RÉSUMÉ : Il est rare que des cardiopathies soient associées aux maladies inflammatoires de l'intestin (MII). La documentation fait état de péricardite, d'épanchement péricardique, de myocardite, d'infarctus du myocarde, d'endocardite et d'arythmie. L'inflammation du myocarde liée aux MII peut être due à une réaction d'hypersensibilité à un médicament

voir page suivante

This article was a winning entry in the Consults in Gastroenterology Case Study Competition, which was initiated and funded by AstraZeneca Canada

Department of Gastroenterology, University of Calgary, Calgary, Alberta

Correspondence: Dr JB Meddings, 3330 Hospital Drive Northwest, Calgary, Alberta T2N 4N1. Telephone 403-220-9356, fax 403-220-8747, e-mail meddings@ucalgary.ca

Received for publication February 28, 2001. Accepted February 28, 2001 
ou à une carence en oligo-éléments ou encore peut être une manifestation extra-intestinale de la MII sous-jacente. La myocardite, dans ce contexte, se présente généralement sous forme d'insuffisance cardiaque congestive ou d'arythmie rebelle. Le pronostic varie selon les cas déclarés, depuis le rétablissement complet jusqu'à l'issue fatale, en passant par la rémission accompagnée d'épisodes récurrents. Le traitement de la myocardite se compose d'aminosalicylates et d'immunosuppresseurs. De nouveaux médicaments pour les MII ont vu le jour récemment, par exemple les antagonistes du facteur de nécrose tumorale alpha (TNF- $\alpha$ ).
Voici le cas d'un homme de 46 ans montrant des signes clini-ques et endoscopiques de la maladie de Crohn du côlon, modérément active, chez qui s'est installée une insuffisance cardiaque congestive, se-condaire à une myocardite à cellules géantes. Les immunosuppresseurs se sont avérés peu efficaces sur le plan clinique. Ce n'est qu'après l'adjonction d'étanercept, un antagoniste du TNF- $\alpha$ du récepteur P75, a-t-on observé une rémission clinique complète. Les auteurs en arrivent à la conclusion que le recours aux antagonistes du TNF- $\alpha$ est envisageable dans les cas de manifestation extra-intestinale potentiellement mortelle d'une MII.
$\mathrm{C}$ ardiac disease in association with inflammatory bowel disease (IBD) is rare. Myocarditis, specifically, may be secondary to drug hypersensitivity reaction or micronutrient deficiency, or due to the inflammatory disease process. There are 20 cases reported in the English literature of myocarditis thought to be directly caused by IBD (1-12). Typically, these patients present at a relatively early age with congestive heart failure or arrhythmias refractory to standard treatment. The course of myocarditis is not predicted by the activity of bowel inflammation. Myocarditis that is thought to be due to the primary IBD is traditionally treated with aminosalicylates or immunosuppressive therapy, such as prednisone and cyclosporine. Newer therapies for IBD, such as thalidomide and tumour necrosis factor (TNF)-alpha antagonists, have not been widely used for the treatment of extraintestinal manifestations of IBD. We report a case of giant cell myocarditis, in a patient with active Crohn's disease, treated with etanercept (Enbrel, Immunex, USA), a TNF- $\alpha$ antagonist.

\section{CASE PRESENTATION}

A 46-year-old gentleman with Crohn's disease presented to the Foothills Medical Centre (Calgary, Alberta) with symptoms of congestive heart failure. He had a history of Crohn's disease diagnosed 19 years earlier at the age of 17 years. The initial Crohn's disease course had been mild and well controlled, but had progressively worsened over the past decade. At the time of admission to hospital, he felt generally unwell, with daily moderate abdominal cramping and seven to eight nonbloody, loose stools per day. He had been steroid-dependent for the previous five years and continued to have moderately active Crohn's disease endoscopically. The most recent endoscopic investigations, completed in February 1998, showed extensive inflammation in the rectosigmoid and descending colon, with multiple inflammatory pseudopolyps. Upper gastrointestinal series and small bowel follow-through x-rays from 1995 showed a $2 \mathrm{~cm}$ segment of distal ileal disease. The patient declined the recommendation from the attending gastroenterologist to consider colectomy. Methotrexate therapy had been attempted in 1993 and 1996 but was discontinued due to rising liver enzyme values. Azathioprine and 6-mercaptopurine had not been used previously. Other IBD-related events included a perianal abscess, treated in 1993; immune thrombocytopenic purpura in 1998, which resolved; and nephrolithiasis in 1999, while the patient was on calcium, vitamin D and didrocal for osteoporosis prevention.
The patient presented in October 1999 with a 5 h history of chest pain and shortness of breath. Two days earlier, he had begun ciprofloxacin treatment for increasing symptoms of colitis, in addition to his usual medications of prednisone $15 \mathrm{mg} /$ day and Salofalk $1500 \mathrm{mg}$ tid. On presentation, he was hypotensive (blood pressure 95/55), tachycardic (120 beats/min) and cushingoid. Respiratory examination was normal, aside from tachypnea. Cardiac auscultation revealed a gallup rhythm with S3 and S4 heart sounds present. The jugular venous pulsation was elevated to $7 \mathrm{~cm}$ above the sternal angle, and a positive hepatojugular reflex was noted, although there was no evidence of pedal edema. Abdominal examination revealed a liver span of approximately $16 \mathrm{~cm}$ in the midclavicular line, extending four fingerbreadths below the costal margin. A pulsatile liver was not found. The abdomen was tender in the left lower quadrant. Perianal examination showed a healed abscess scar and multiple skin tags. Results of a rectal examination revealed slight tenderness.

The electrocardiogram showed evidence of anterior and inferior infarction (ST elevation in V1 to V3, II, III and avF with reciprocal changes in the lateral leads). On echocardiogram, the right ventricle (RV) was severely hypokinetic, and the left ventricle (LV) was moderately to severely hypokinetic. Immediate catheterization confirmed moderate to severe LV systolic dysfunction with an ejection fraction of $19 \%$. Coronary angiography was normal. Pulmonary artery catheterization showed a cardiac index of only 1.3. The patient was admitted to coronary intensive care and required intra-aortic balloon pump, dopamine and adrenaline for stabilization.

Following admission, an endocardial biopsy was completed, which revealed severe acute giant cell myocarditis, with lymphocytes, polymorphs, eosinophils and multinucleated giant cells present. Stains for acid-fast bacilli and fungus were negative. Other investigations showed an elevated white blood cell count $\left(18.6 \times 10^{6} / \mathrm{L}\right)$ and platelet count $\left(560,000 \times 10^{9} / \mathrm{L}\right)$. The hemoglobin level was normal at $122 \mathrm{~g} / \mathrm{L}$, as were levels of general electroytes and creatinine. The albumin level was only $24 \mathrm{~g} / \mathrm{L}$. Liver chemistry levels were abnormal on admission (aminotransferase $650 \mathrm{U} / \mathrm{L}$, alkaline phosphatase $295 \mathrm{U} / \mathrm{L}$, gamma glutamyl transferase $535 \mathrm{U} / \mathrm{L}$ and bilirubin $9 \mu \mathrm{mol} / \mathrm{L}$ ) but normalized within $24 \mathrm{~h}$. The creatinine kinase level was elevated at $218 \mathrm{U} / \mathrm{L}$, with a relative cardiac index of 158 (normal 0-4). Viral studies, human immunodeficiency virus and hepatitis serology, and ferriten levels were normal. 
Immunosuppressive treatment was initiated with an increase in corticosteroids (hydrocortisone sodium succinate [Solu-cortef; Pharmacia \& Upjohn, USA] $125 \mathrm{mg}$ intravenous tid) and the addition of intravenous immunoglobulin $(126 \mathrm{~g})$ and cyclophosphamide $\left(375 \mathrm{mg} / \mathrm{m}^{2} /\right.$ day for two days). Some clinical improvement was apparent, but the patient still required ionotropic support seven days later. Etanercept, obtained by compassionate release, was administered intravenously $\left(32 \mathrm{mg} / \mathrm{m}^{2}\right)$ and continued subcutaneously $\left(16 \mathrm{mg} / \mathrm{m}^{2}\right)$ twice weekly. Ionotropes were discontinued $24 \mathrm{~h}$ later, and the patient was discharged from hospital seven days after the initiation of etanercept treatment with no signs or symptoms of congestive heart failure. Echocardiogram at discharge showed substantial improvement with only mild global cardiac impairment, dilated RV and hypokinesis of the inferior wall. The hospital course was otherwise complicated by administering $72 \mathrm{~h}$ of empirical antibiotics for Gram-positive cocci in blood cultures until contamination with Streptococcus sanguis was confirmed. A small upper gastrointestinal bleed due to Mallory-Weiss tear was confirmed by endoscopy. Discharge medications included prednisone, etanercept, spironolactone, carvedilol, digoxin, captopril, amitriptyline, maxeran and omeprazole.

Over the next several weeks, the patient was well, with no return of symptoms. Unfortunately repeat endocardial biopsy one month after the original presentation showed no histological improvement, with persistant florid giant cell myocarditis and necrosis. Repeat echocardiogram was unchanged from hospital discharge. Due to ongoing histological inflammation and the lack of echocardiographic improvement, cyclophosphamide was again administered $\left(750 \mathrm{mg} / \mathrm{m}^{2}\right)$ and azathioprine was started $(50 \mathrm{mg} /$ day $)$. In the next four weeks, the patient developed increasing shortness of breath and fatigue. Repeat echocardiogram showed intracardiac thrombus, and warfarin was started. Despite this, his symptoms progressed and he was readmitted for congestive heart failure. At this time, echocardiogram showed a dilated RV, an LV with very poor overall systolic function and moderate tricuspid regurgitation. He was started on milronone ionotropic treatment and listed for cardiac transplantation. He developed acute renal failure and died of cardiogenic shock en route to cardiac transplantation 69 days after his initial presentation with congestive heart failure. No postmortem examination was completed.

\section{DISCUSSION}

IBD is a chronic relapsing and remitting disorder, the etiology of which is thought to be a combination of genetic host susceptibility, environmental factors and an imbalance of the immune system. Extraintestinal manifestations are present in up to $42 \%$ of patients with colonic disease and $23 \%$ of those with inflammation of the small bowel (13). Most extraintestinal manifestations follow the clinical course of IBD, while some manifestations such as axial arthritis and schlerosing cholangitis may run a course independent of symptoms of bowel disease activity. Treatment of Crohn's disease and ulcerative colitis has traditionally involved antibiotics, aminosalicylates and immunosuppressants, such as corticosteroids, azathioprine, 6-mercaptopurine, methotrexate and cyclosporine. These treatments also influence the extraintestinal manifestations to some extent, particularly those that follow the course of IBD activity. Some newer therapies for IBD (such as thalidomide and TNF- $\alpha$ antagonists) have focused on different immunosuppressive pathways. The role of these more recent treatments in the management of extraintestinal manifestations of IBD is largely unknown.

Cardiac involvement due to IBD is rare, usually presenting as myocarditis (1-12) or pleuropericarditis (14-17). Myocarditis may be due to IBD drug therapy, selenium deficiency or the primary disease itself. Multiple case reports have demonstrated the association between aminosalicylates and the development of drug-induced myocarditis $(18,19)$. Histologically, this presents as perivascular infiltration of the myocardium with eosinophils, lymphocytes and histiocytes. These cases generally respond to discontinuation of the drug class, usually with complete resolution of cardiac symptoms. Selenium deficiency has been reported as the cause of myocarditis-induced cardiomyopathy in two patients with Crohn's disease receiving total parenteral nutrition (TPN). The first case involved a patient on TPN for eight years who had selenium levels after death from cardiogenic shock at less than $1 \%$ of normal. Autopsy showed monocellular myocardial inflammation (6). The second case involved a patient on TPN for only 19 days, with selenium levels in various tissues at $5 \%$ to $12 \%$ of normal. The reduced cardiac function resolved with selenium replacement (4).

Myocarditis may be due to a number of etiologies, including viral, drug-related and idiopathic forms. Idiopathic giant cell myocarditis is a rare entity; little is known about its natural history. Most information comes from the Giant Cell Myocarditis Study Group, formed as a multicentre international effort to gather information (2). Through advertising to physicians via cardiac journals, 63 cases were documented and published from 49 centres in 16 countries. Generalizations from this cohort suggest that giant cell myocarditis affects a reasonably young population with an average age at presentation of 42 years (range 16 to 69 years). The most common presenting diagnoses were congestive heart failure $(75 \%)$ and arrhythmia (14\%). Prognosis was poor, as $89 \%$ of patients preceded to death or cardiac transplantation with a median survival of only 5.5 months. In addition, there was a high death rate among patients receiving heart transplants (26\% over 3.7 years), and recurrence was noted in nine of the 34 transplanted patients. Of the 63 patients, most were treated with immunosuppressive drugs, which improved median survival to up to 12 months, with the longest survival reported in patients treated with combination immunosuppression, particularly corticosteroids and azathioprine or cyclosporine combinations. Three patients were treated with muromonab antibodies: one survived and was well at 28 months of followup, while two others died (one after cardiac transplant). No patients were treated with TNF- $\alpha$ antagonists. 
Myocarditis due to primary IBD has been reported in 15 published cases (1-12), as well as five additional patients discovered in the Giant Cell Myocarditis cohort analysis (2). The largest case series was a Danish study accessing a database of more than 15,000 IBD patients (7). Only six cases of myocarditis were noted. Of the 15 total cases reported to date, at least nine patients were not receiving treatment with aminosalicylates. Selenium levels were not generally tested, but no patients were reported to be on TPN at diagnosis of the myocarditis. Myocardial symptoms did not appear to follow those of active bowel inflammation, and, in fact, one case described myocarditis before the diagnosis of Crohn's disease (3). One study noted that myocarditis was more common at the beginning of an IBD exacerbation and that there was usually more than one extraintestinal manifestation present (8). Treatments for myocarditis have varied, including aminosalicylates, prednisone and cyclosporine (20). Prognosis has also been variable, and relapses have been reported (8). No patients, to our knowledge, have been treated with TNF- $\alpha$ antagonists for cardiac extraintestinal manifestations of Crohn's disease.

TNF is a proinflammatory cytokine thought to be an integral component in the inflammation cascade of IBD. It has a broad spectrum of proinflammatory effects including activation of macrophages, activation of granulocytes and induction of adhesion molecule expression by vascular endothelium, which promotes influx of inflammatory cells into the mucosa. Furthermore, TNF has a procoagulant effect in the vascular endothelium and promotes the release of nitric oxide, platelet-activating factor and prostacyclin. In addition, TNF may increase the production of metalloproteinases that are directly involved in tissue breakdown (21).

Infliximab, the first TNF- $\alpha$ antagonist approved for use in Crohn's disease, is a murine monoclonal immunoglobulin G1 antibody directed against TNF- $\alpha$. Its effectiveness in treating Crohn's disease has been favourable in terms of clinical response, endoscopic improvement and fistulae closing. Etanercept (Enbrel) is a TNF- $\alpha$ receptor antagonist that has been used extensively in the treatment of rheumatoid and psoriatic arthritis. As opposed to infliximab (which is a chimeric human-mouse antibody), etanercept is a recombinant molecule derived from a naturally occurring TNF antagonist and consists of a TNF receptor joined to the Fc domain of a human immunoglobulin G1 molecule. Its use in IBD is currently being established.

While evidence of efficacy of etanercept in IBD is being evaluated, there is preliminary evidence that it may be of use in the generic treatment of congestive heart failure. TNF- $\alpha$ may contribute to the pathogenesis of congestive heart failure, and in animal models of cytokine-induced dilated cardiomyopathy, injection of a soluble TNF receptor abrogated myocardial inflammation (22). Recently, patients with significant congestive heart failure were enrolled in a dose-escalation study of etanercept. Compared with placebo, the patients receiving 4 or $10 \mathrm{mg} / \mathrm{m}^{2}$ of etanercept had a significant increase in quality of life scores and in cardiac ejection fraction (23), which persisted over a three-month period on biweekly maintenance doses of 5 of $12 \mathrm{mg} / \mathrm{m}^{2}$ (24).

In the case presented, known causes of myocarditis, such as viral, ischemic and hypertensive disorders, were ruled out. Although the patient was on mesalamine (Salofalk; Axcan Pharma Inc, Canada), the histological picture was not consistent with drug-related myocarditis, and clinical improvement did not occur with its withdrawal. Selenium levels were not examined, but the patient was not on TPN before he presented with myocarditis. Therefore, the myocarditis was most likely a manifestation of Crohn's disease.

In comparison with the largest cohort of patients with giant cell myocarditis, our patient had a similar age, presentation and, unfortunately, outcome. Clinically, he appeared to respond to aggressive combination immunosuppressive therapy with prednisone, intravenous immunoglobulin, cyclophosphamide and Enbrel. His initial hospital course appeared to respond rapidly to the addition of Enbrel , with complete clinical resolution of symptoms. Echocardiographic improvement was impressive but not complete. In previously published case reports of myocarditis due to IBD, clinical and histological improvement generally took up to three months $(3,8)$. Histological improvement in our patient was not demonstrated. No other cases have attempted to document histological recovery.

\section{CONCLUSIONS}

The present report describes a case of giant cell myocarditis associated with Crohn's disease, which appeared to respond initially to treatment with combination immunosuppression and Enbrel. The full potential of TNF- $\alpha$ antagonists has not yet been uncovered, and potential roles in the treatment of extraintestinal manifestations of IBD may be possible. Further research in the use of TNF- $\alpha$ antagonists is ongoing, and consideration for its use in life-threatening extracolonic IBD should be considered on a case-by-case basis.

\section{REFERENCES}

1. Ariza A, Lopez MD, Mate JL, Curos A, Villagrasa M, Navas-Palacios JJ. Giant cell myocarditis: Monocytic immunophenotype of giant cells in a case associated with ulcerative colitis. Hum Pathol 1995;26:121-3.

2. Cooper LT, Bery GJ, Shabetia R. Idiopathic giant-cell myocarditis Natural history and treatment. N Engl J Med 1997;336:1860-6.

3. Frid C, Bjarke B, Eriksson M. Myocarditis in children with inflammatory bowel disease. J Pediatr Gastroenterol Nutr 1986;5:964-5.

4. Levy JB, Jones HW, Gordon AC. Selenium deficiency, reversible cardiomyopathy and short-term intravenous feeding. Postgrad Med J 1994;70:235-6

5. McKeon J, Haagsma B, Bett JHN, Boyle CM. Fatal giant cell myocarditis after colectomy for ulcerative colitis. Am Heart J 1986;111:1208-9.

6. Quercia RA, Korn S, O’Neill D, et al. Selenium deficiency and fatal cardiomyopathy in a patient receiving long-term home parenteral nutrition. Clin Pharm 1984;3:531-5.

7. Sorenson HT, Fonager KM. Myocarditis and inflammatory bowel disease: A 16-year Danish nationwide cohort study. Dan Med Bull 1997;44:442-4.

8. Weiss N, Rademacher A, Zoller WG, Schlondorff D. Myocarditis and subcutaneous granulomas in a patient with Crohn's disease of the colon. Am J Med 1995;99:434-6.

9. Case reports of the Massachusetts General Hospital. N Engl J Med 1982;306:1215-23 
10. Wohgelernter D, Otis CN, Batsford WP, Cabin HS. Myocarditis presenting with "silent" left atrium and left thrombus. Am Heart J 1984;108:1557-8.

11. Humbert P, Faivre R, Fellman D, Bassand JP, Dupond JL. Giant cell myocarditis: an autoimmune disease? Am Heart J 1988; $155: 485-7$.

12. Becker SA, Wishnitzer R, Botwin S, Eliraz A, Bass DD. J Clin Gastroenterol 1981;2:267-70.

13. Greenstein AJ, Janowitz HD, Sachar DB. The extra-intestinal complications of Crohn's disease and ulcerative colitis: a study of 700 patients. Medicine 1976;55:401-12.

14. Breitenstein RA, Salel AF, Watson DW. Chronic inflammatory bowel disease: Acute pericarditis and pericardial tamponade. Ann Intern Med 1974;81:406.

15. Mukhopadhyay D, Nasr K, Grossma BJ, Kirser JB. Pericarditis associated with inflammatory bowel disease. JAMA 1970;211:1540-2.

16. Patwardhan RV, Heilpern RJ, Brewster AC, Darrah JJ. Pleuropercarditis: an extraintestinal complication of inflammatory bowel disease. Arch Intern Med 1983;143:94-6.
17. Rheingold OJ. Inflammatory bowel disease and pericarditis. Ann Intern Med 1975;21:760-3.

18. Agnholt J, Sorensen HT, Rasmussen SN, Gotzsche C, Halkier P. Cardiac hypersensitivity to 5-amino salicylic acid. Lancet 1989;i:1135.

19. Kristensen KS, Hoegholm A, Borh L, Friis S. Fatal myocarditis associated with mesalazine. Lancet 1990;335:605.

20. Wilson MS, Barth RF, Baker PB, et al. Giant cell myocarditis. Am J Med 1985;79:647-52.

21. Sands BE. Therapy of inflammatory bowel disease. Gastroenterology 2000;118:S68-82.

22. Kubota T, Bounoutas GS, Miyagishima M, et al. Soluble tumor necrosis factor receptor abrogates myocardial inflammation but not hypertrophy in cytokine-induced cardiomyopathy. Circulation 2000;101:2518-25

23. Deswal A, Bozkurt B, Seta Y, et al. Safety and efficacy of a soluble P75 tumor necrosis factor receptor (Enbrel, etanercept) in patients with advanced heart failure. Circulation 1999;99:3224-6.

24. Bozkurt B, Torre-Amione G, Warren MS, et al. Results of a targeted anti-tumor necrosis factor therapy with etanercept (ENBREL) in patients with advanced heart failure. Circulation 2001;103:1044-7. 


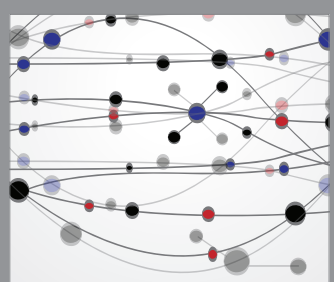

The Scientific World Journal
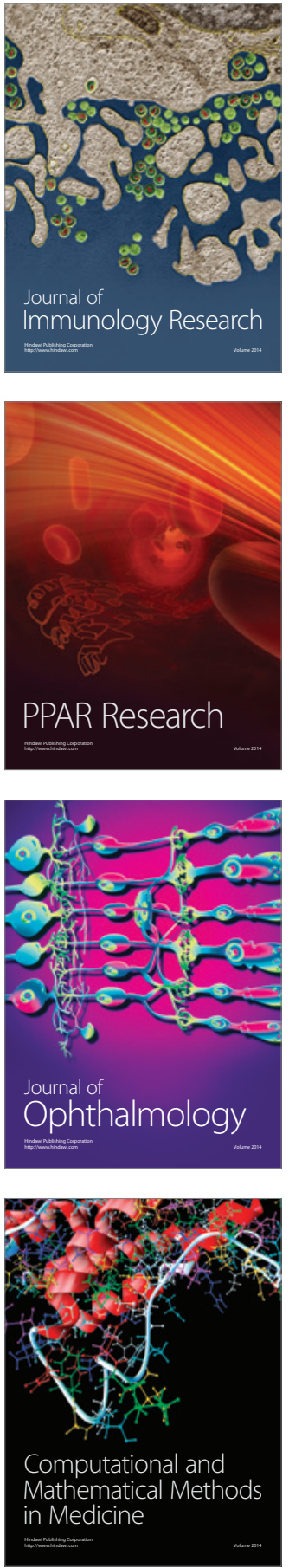

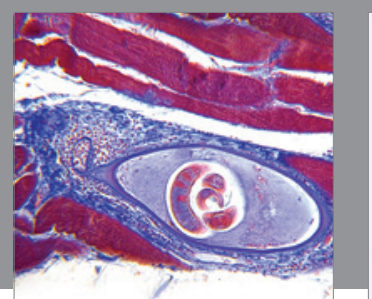

Gastroenterology Research and Practice

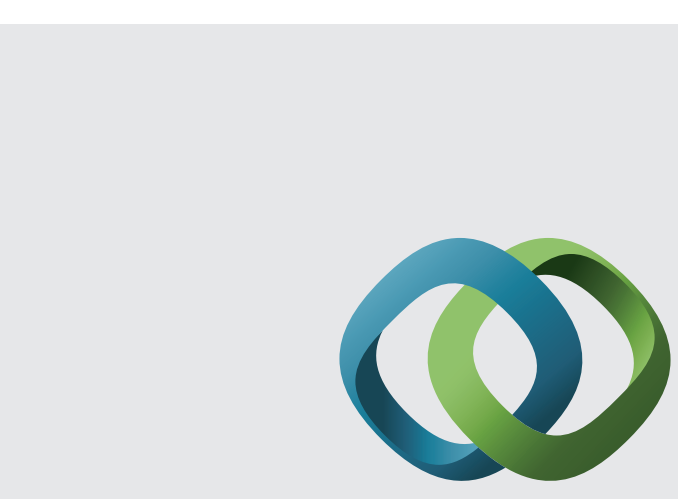

\section{Hindawi}

Submit your manuscripts at

http://www.hindawi.com
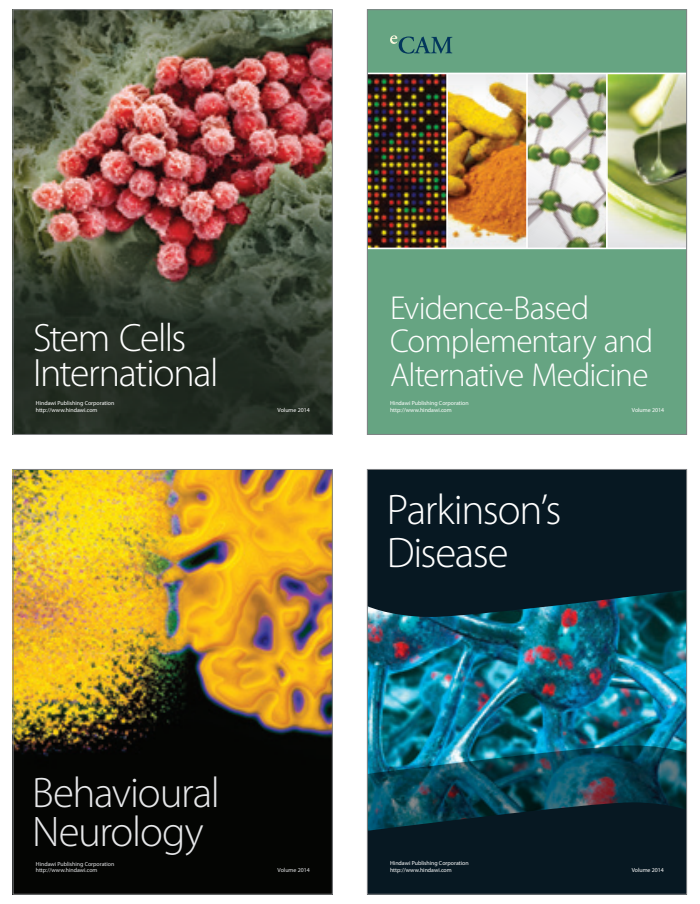
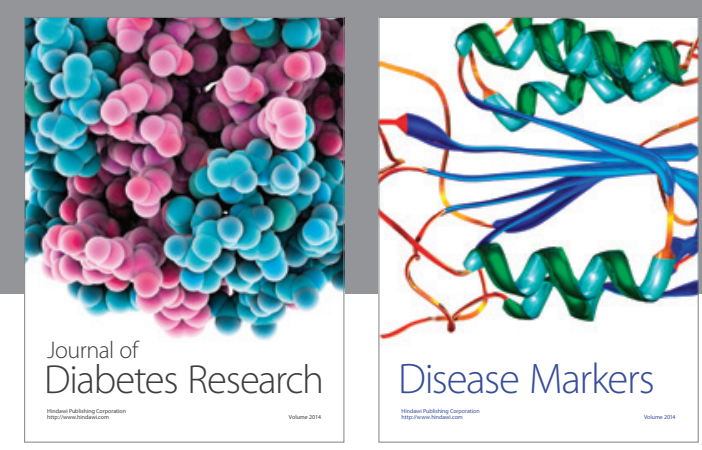

Disease Markers
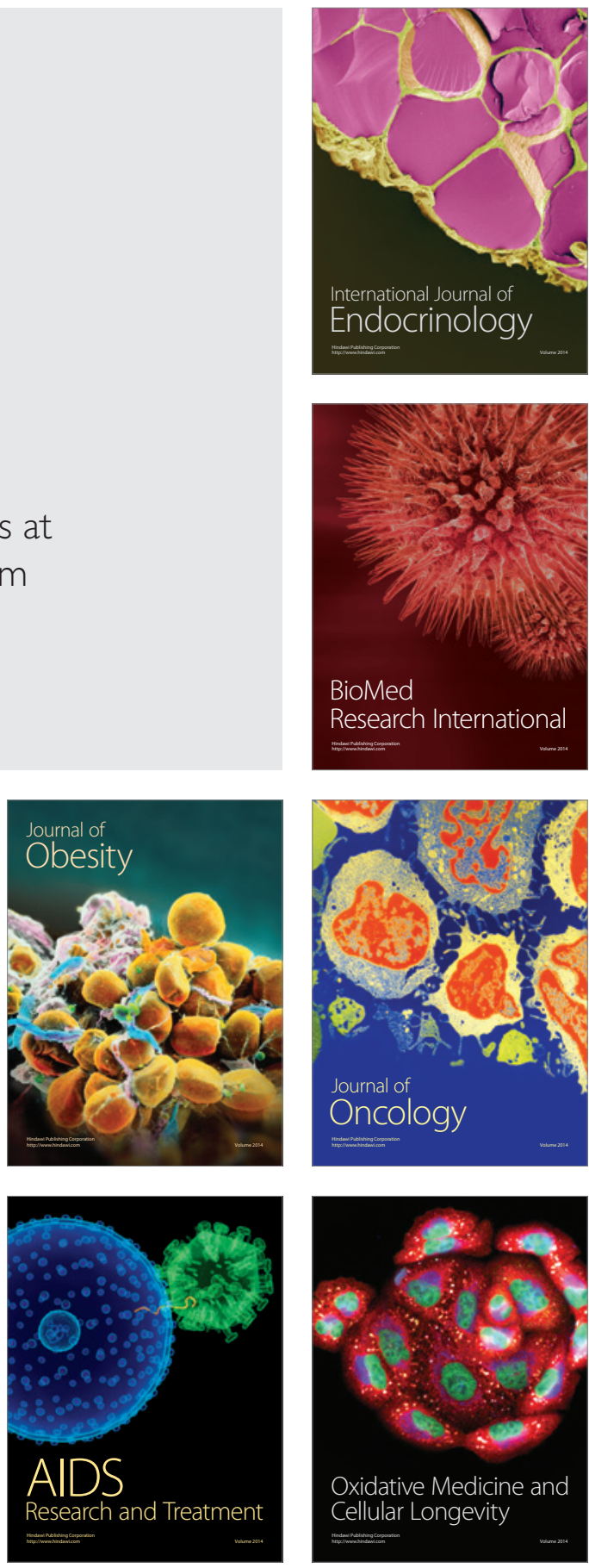